\title{
Role of micronucleus test in predicting breast cancer susceptibility: a systematic review and meta-analysis
}

\author{
F Cardinale', P Bruzzi' and C Bolognesi*,2 \\ 'Clinical Epidemiology Unit, National Cancer Research Institute, Largo R Benzi 10, 16132 Genoa, Italy; ${ }^{2}$ Environmental Carcinogenesis Unit, National \\ Cancer Research Institute, Largo R Benzi 10, 16132 Genoa, Italy
}

BACKGROUND: The cytokinesis-block micronucleus test (MNT), as a marker of chromosomal mutagen sensitivity, was applied in a number of studies enrolling breast cancer (BC) patients and subjects with known or putative genetic predisposition to BC. The large majority of them involve the evaluation of induced micronuclei $(\mathrm{MN})$ frequency in peripheral lymphocytes, after the in vitro challenge with ionising radiations.

METHODS: The aim of the present systematic review and meta-analysis is to investigate the role of MN assay in the identification of individuals at increased risk of $\mathrm{BC}$ and its potential use as prescreening test in women with a family history $(\mathrm{FH})$ of $\mathrm{BC}$.

RESULTS: Twelve studies were included in the meta-analysis, covering a time interval 1998-2007, and including 752 cases and 593 controls. Among the cases, 629 are cancer patients and 123 are cancer-free subjects, including 32 first-degree relatives of the susceptible subjects and 9I BRCAI/2 mutation carriers. Our meta-analysis reveals a significant increase of baseline MN frequency related to cancer status, but the association with $\mathrm{FH}$ of $\mathrm{BC}$ and specifically with BRCA mutations is not clear. $\mathrm{A}$ larger difference in $\mathrm{MN}$ frequency between cases and controls was observed after in vitro challenge, but response to radiation exposure doesn't appear to better discriminate cancer-susceptible subjects.

CONCLUSION: Our study suggests the presence of some bias affecting many of these studies, reinforcing the suggestion that a more rigorous study design is needed in this area.

British Journal of Cancer (2012) 1 06, 780-790. doi:I0.1038/bjc.20 I I.567 www.bjcancer.com

Published online 20 December 2011

(C) 2012 Cancer Research UK

Keywords: micronucleus test; breast cancer; family history; BRCAI/2; systematic review

The micronucleus test (MNT), as a marker of chromosomal damage, is a well-established assay in genetic toxicology and in human biomonitoring (Fenech, 2007). The MNT is one of the most widely applied assays to test new compounds, in vitro and in vivo, for regulatory purposes (OECD TG 474, 1997; OECD TG 487, 2009). The test is also successfully used in monitoring human populations exposed to genotoxic compounds; recommendations for the appropriate application are available (Albertini et al, 2000; Battershill et al, 2008). Recent prospective studies evaluating large cohorts of disease-free subjects revealed that an increase in micronuclei $(\mathrm{MN})$ frequency in peripheral lymphocytes was associated with an increased risk of cancer, at the population level, providing a suggestive evidence that this biomarker could be predictive of cancer risk (Bonassi et al, 2007; Murgia et al, 2008).

Many papers were published on the application of the $\mathrm{MN}$ in peripheral lymphocytes of patients with cancer or preneoplastic lesions; the large majority of them show a significant increase of MN frequency in patients compared with control groups, with a large variability among the tumours and studies (Iarmarcovai et al, 2008; Bonassi et al, 2011; El-Zein et al, 2011). Increased MN frequency was also detected in peripheral lymphocytes of subjects affected by cancer-associated congenital syndromes characterised

*Correspondence: Dr C Bolognesi; E-mail: claudia.bolognesi@istge.it Received 5 August 2011; revised 18 November 2011; accepted 24 November 20 I ; published online 20 December $201 \mathrm{I}$ by deficiency in DNA damage response, such as Fanconi anaemia (Maluf and Erdtmann, 2001), Bloom syndrome or ataxia telangiectasia (Scott et al, 1996). Furthermore, the MN frequency in human peripheral lymphocytes or other surrogate tissues was shown to be influenced by genetic polymorphisms in various genes involved in DNA repair pathways or in xenobiotic metabolism, which are responsible for the interindividual differences in response to genotoxins (Dhillon et al, 2011). On the basis of these findings, the $\mathrm{MN}$ expression appears to be greatly modulated by the inherited and acquired deficiencies in host defence mechanisms against genotoxic compounds. Mutagen sensitivity, measured by quantifying the genotoxic events induced by chemical or physical agents in short-term cultures of peripheral blood lymphocytes, was used with the aim to improve the detection of the individual genetic susceptibility, reducing the influence of environmental factors. The heritability of mutagen sensitivity was shown in a number of studies involving first-degree relatives of cancer patients (Scott et al, 1998; Burrill et al, 2000) and in a classic twin study (Surowy et al, 2011).

A large proportion of the available studies on $\mathrm{MN}$ application as mutagen sensitivity assay was conducted in breast cancer (BC) patients and subjects with known or putative genetic predisposition to BC. Ionising radiation was the most frequently applied challenge agent in these studies, due to its potential to induce highly mutagenic genetic events allowing to estimate the inherited deficiency in DNA repair machinery, associated with known BC susceptibility genes. 
Enhanced mutagen sensitivity, evaluated as the increase in MN frequency in peripheral lymphocytes from BC patients and subjects with a strong family history (FH) of BC, was observed in the initial studies (Scott et al, 1998, 1999; Burrill et al, 2000) and encouraged further investigations. Increase in $\mathrm{MN}$ radiation induced in small groups of healthy women carrying a BRCA1/2 mutation compared with matched control groups (Rothfus et al, 2000; Trenz et al, 2002, 2003) suggested a close relationship between the presence of these mutations and the MN induction by ionising radiations. Further studies didn't confirm this finding and showed an increased MN frequency associated to in vitro radiation exposure in sporadic BC patients (Varga et al, 2006), suggesting a different role of the assay.

A number of studies are now available on mutagen sensitivity, evaluated as an increased $\mathrm{MN}$ frequency in challenge assay, in different groups of sporadic and familial BC patients and in their relatives. Published studies are generally based on small size samples. As a consequence, comprehensive and reliable conclusions cannot be afforded by the results of individual studies, due to inadequate statistical power.

The aim of the present study was to retrieve, review and synthesise published evidence on this subject to define the role of this biomarker in the identification of individuals at increased risk of $\mathrm{BC}$ and its potential use as a prescreening test in women with a $\mathrm{FH}$ of BC.

\section{MATERIALS AND METHODS}

This systematic review follows the methodology described in the PRISMA statement (Moher et al, 2009)

\section{Eligibility criteria}

Eligible for the inclusion in the present review were all the casecontrol studies in which MNT was performed at baseline and after irradiation in women with $\mathrm{BC}$ or at risk of $\mathrm{BC}$ because of $\mathrm{FH}$.

\section{Search strategy}

Studies on the application of the MNT in BC patients with hereditary/familial factors were identified by using the MedLine/ PubMed database (National Library of Medicine, National Institutes of Health, Bethesda, MD, USA; http://www.ncbi.nlm. nih.gov/pubmed/).

The terms 'micronucleus' and 'micronuclei' were used as medical subject heading associated to 'breast neoplasm', using AND operator. Only the studies including the radiation sensitivity assay were considered.

\section{Study selection}

All retrieved studies were reviewed and assessed by two of us ( $\mathrm{CB}$ and FC) for inclusion in the present analysis. A number of publications were discarded, because the groups of patients considered were partially or completely overlapping with those included in other studies from the same research groups. Only studies reporting an adequate experimental protocol with reference to established criteria of MN scoring were included in the meta-analysis.

\section{Data collection process}

For each study, the following information was collected: the number of cases and respective controls, the MN frequency before and after irradiation with its s.e. where available, the clinical characteristics of the cases, the FH and the BRCA status, when assessed, and the different type and doses of irradiation.

\section{Classification of individual studies}

Most of the studies clearly indicated the controls as negative or positive for all the three factors under study (tumour-FH-BRCA status). In the remaining studies, controls were arbitrarily considered negative for all the three factors, if no mention of positivity was made for any of them.

Other potential sources of heterogeneity are represented by the following: age and sex of subjects tested; method of subject recruitment; smoking habits; prior exposure to radiotherapychemotherapy; stage of the disease (early advanced); collection method of blood sample (timing, conservation and treatment); the experimental protocol; number of cells scored; type of irradiation (source and dose rate). All these information, when available, were recorded and discussed in the results section.

\section{Statistical analyses}

The primary aim of this study was to assess the potential association between MN frequency, both at baseline and after irradiation, and presence of $\mathrm{BC}, \mathrm{FH}$ of $\mathrm{BC}$ or a pathogenic mutation in a BRCA gene. Accordingly, within each study, the number of cases had to be identified that was relevant for each of these study questions. This led to the creation of subgroups of cases within each study. For each subgroup, cases were compared with the respective controls (subjects without $\mathrm{BC}$, or with a negative $\mathrm{FH}$ for $\mathrm{BC}$ or negative/not evaluated for BRCA mutations).

From each publication, the MN frequency in each group of cases and controls, at baseline and after irradiation was abstracted. The primary contrasts examined were: (1) presence or absence of cancer (stratifying for $\mathrm{FH}$ ); (2) positive or negative $\mathrm{FH}$ (stratifying for tumour status); (3) positivity or negativity/not evaluated for BRCA (stratifying for tumour status in FH-positive subjects).

From each study, the difference, with its s.e. and 95\% confidence intervals (CI) at baseline and after irradiation, between cases and controls was computed. Log transformations, possibly more appropriate with $\mathrm{MN}$ frequency data, were not possible because individual data were not available.

Study-specific differences in MN frequency were pooled across studies; first within subgroups homogeneous for primary contrast and stratifying factors, and then across strata homogeneous for primary contrast by computing the weighted mean difference (WMD) with its $95 \% \mathrm{CI}$ and $P$-value. The weight assigned to each study was $1 /$ variance of the study-specific mean difference (Sutton et al, 2004). Meta-analysis was performed using a random effects model. Student's $t$-test was also performed to assess the significance of differences between means within subgroups. The heterogeneity within each set of values was examined with a standard $Q$-test statistic (testing the hypothesis of homogeneity) The results of these analyses are presented in three pairs of Forrest plots, each for a primary contrast, at baseline and after in vitro irradiation, where also stratum-specific, summary weighted differences are reported.

\section{RESULTS}

\section{Results of the literature search}

The literature search was carried out on March 2010. Its results and the stepwise exclusion process is described in Figure 1. A total of 75 papers were retrieved and screened; 57 of them were discarded because they were not pertinent to our analysis for a number of reasons, as described in the flow chart.

Fifteen full-text articles were assessed for eligibility and three of them were excluded because the numerical results were not provided (Djuzenova et al, 2006), or because the study groups had been already used in previous studies (Baeyens et al, 2002, 2005b) 


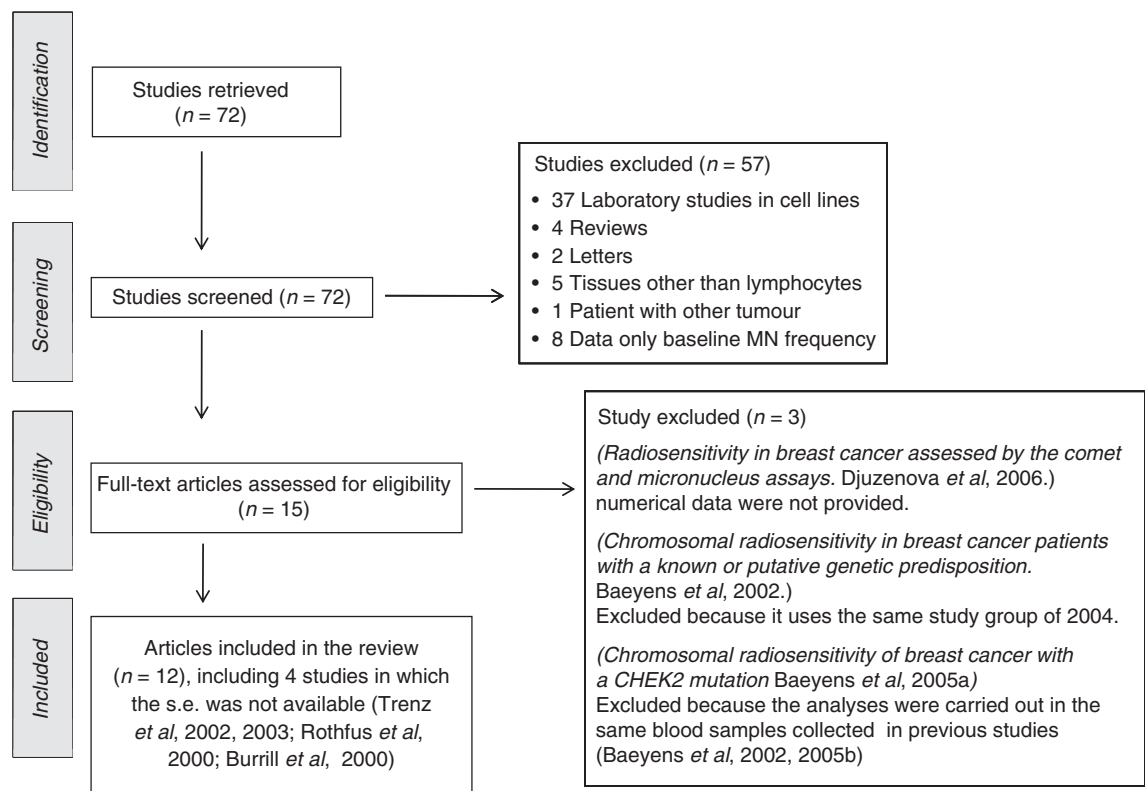

Figure I Flow chart: selection of the literature.

As a consequence, 12 articles (Table 1) were left for the inclusion in the review, including 4 studies in which the s.e. was not available (Burrill et al, 2000; Rothfus et al, 2000; Trenz et al, 2002, 2003).

\section{Description of the studies}

The characteristics of the selected studies are reported in Table 1. A total of 752 BC cases and 593 controls were included in the analysis. A total of 629 cases are BC patients; 266 of them were reported as unselected and 274 as sporadic, 11 as index cases; 78 are cases with $\mathrm{FH}, 26$ as BRCA1/2 positive, 52 as BRCA1/2 negative. A total of 123 cases were cancer-free; it included 22 first-degree relatives of the index cases, 57 women with mutation (BRCA1/2), 34 relatives with mutation (BRCA1/2) and 10 relatives without mutation. A total of 593 controls were reported as healthy subjects/ normal volunteers, 44 were defined as subjects without any FH of cancer and 25 as mutation-negative females from the same families of the cases. Age of cases and controls including the respective ranges is reported only in nine studies.

The blood samples were collected at different times before, during or after the chemotherapy/radiotherapy. For 396 BC patients, no exposure to chemotherapy/radiotherapy during or before sampling was reported; 69 were exposed to radiotherapy before or during sampling; one study reported that 47 cases were sampled between diagnosis and start of the therapy or when therapy was finished.

Only two studies collected data on health status, lifestyle factors and presence of concomitant therapies (Trenz et al, 2002; Kotsopoulos et al, 2007). In seven studies, the previous or concomitant use of antibiotics, tamoxifen or radio-chemotherapy was considered (Scott et al, 1998, 1999; Baeyens et al, 2004, 2005b; Ban et al, 2004; Mozdarani et al, 2005; Varga et al, 2006). Smoking habits were collected in only three studies (Ban et al, 2004; Varga et al, 2006; Kotsopoulos et al, 2007).

In different subgroups, the frequency of $\mathrm{MN}$ in cases and controls was analysed only at baseline or only after irradiation (at different dose rate) or in both cases.

\section{Laboratory methods}

All the studies selected for the meta-analysis applied the cytokinesis-block micronucleus assay (Fenech, 2007). The experimental protocols used were very heterogeneous (Table 1). High doses ( $1-3.5 \mathrm{~Gy})$ of ionising $x$ - or $\gamma$-radiations from different sources, cobalt 60 or caesium 137, were used as challenge agents for the in-vitro sensitivity assay.

Different irradiation procedures were adopted in the different studies: low-dose rate $\left(0.10-0.40 \mathrm{cGy} \mathrm{\textrm {min } ^ { - 1 } )}\right.$ or high-dose rate $\left(0.7-4 \mathrm{~Gy} \mathrm{~min}^{-1}\right)$.

Different times between the irradiation and cell culture $(0-3 \mathrm{~h})$ and different harvesting times (from 69-90 h) were applied in the studies. All the studies refer to established scoring criteria, although none considered the most advanced cytome protocol recently proposed (Fenech, 2007). All the studies reported the scoring of 1000 binucleated cells for MN analysis, with the exception of Scott et al (1998, 1999), Burrill et al (2000) and Kotsopoulos et al (2007), where 100-200 cells were analysed. No statistical significant difference in mean $M N$ frequency (Student's $t$-test) was observed in studies scoring 100-200 cells. We didn't consider this deviation from the established $\mathrm{MN}$ protocol as a prejudice for the inclusion in our meta-analysis.

One study reports also an exercise on a subgroup of subjects using the automatic system for MN scoring.

\section{Subgroups of patients and controls}

A total of 51 different subgroups of cases, defined by their characteristics (presence of $\mathrm{BC}$, presence of a $\mathrm{FH}$ of $\mathrm{BC}$ and presence of a pathogenic mutation in a $B R C A$ gene) were identified within the 12 studies (Table 2). For each subgroup, cases were compared with the controls (subjects without $\mathrm{BC}$, and with a negative $\mathrm{FH}$ for $\mathrm{BC}$ and negative/not evaluated for BRCA mutations).

Student's $t$-test was performed to evaluate differences between high-dose rate and low-dose rate subgroups. The test did not show statistically significant differences between the two groups.

Funnel plots of all studies, at baseline and on irradiated cells, failed to provide any evidence of publication bias, even though they confirmed the large variability of results across studies.

\section{MN frequency in different subgroups}

Presence vs absence of $B C$ There were 16 contrasts available to assess the difference in the baseline $\mathrm{MN}$ frequency between 
Table I Characteristics of the 12 studies included in the meta-analysis on MN and breast cancer

\begin{tabular}{|c|c|c|}
\hline Reference & $\begin{array}{l}\text { Contrast } N \\
\text { in Table } 2\end{array}$ & Cases \\
\hline $\begin{array}{l}\text { Scott et al } \\
\text { (1998) }\end{array}$ & $1-2$ & $\begin{array}{l}39 \text { breast cancer patients } \\
\text { Without any exposure to } \\
\text { chemotherapy or radiotherapy before } \\
\text { sampling } \\
\text { Age } 58.5 \text { (7.4) range }(35-70)\end{array}$ \\
\hline $\begin{array}{l}\text { Scott et al (1999) } \\
\text { Extension of the } \\
\text { previous study } \\
\text { (Scott et al, 1998) }\end{array}$ & 3 & $\begin{array}{l}\text { I } 30 \text { breast cancer patients } \\
\text { Without any exposure to } \\
\text { cytotoxic chemotherapy before } \\
\text { sampling } \\
\text { Age } 57 \text { range }(30-75)\end{array}$ \\
\hline $\begin{array}{l}\text { Burrill et al } \\
(2000)\end{array}$ & $4-5$ & $\begin{array}{l}\text { I I index cases (level of radiation } \\
\text { sensitivity }>\text { cut off) } \\
\text { The cases were selected } \\
\text { among the sensitive cases from breast } \\
\text { cancer patients } \\
\text { (Scott et al, 1999) } \\
22 \text { first-degree relatives } \\
\text { of the index cases }\end{array}$ \\
\hline $\begin{array}{l}\text { Rothfus et al } \\
\text { (2000) }\end{array}$ & $6-7$ & $\begin{array}{l}22 \text { members of } 13 \text { families with a } \\
\text { familial BRCAI mutation } \\
\text { Age } 42 \text { (I0) range } 23-58\end{array}$ \\
\hline $\begin{array}{l}\text { Trenz et al } \\
\text { (2002) }\end{array}$ & $8-9$ & $\begin{array}{l}\text { I } 0 \text { women carrying a familial BRCA I } \\
\text { mutation } \\
9 \text { women with a familial } \\
\text { BRCA2 mutation. }\end{array}$ \\
\hline
\end{tabular}

Trenz et al

(2003)

Ban et al (2004)

$11-13$

130 unselected breast cancer patients 58 without radiotherapy

69 radiotherapy during

and before blood

sampling

Age 53.2 (10.8) range (26-78)

Baeyens et a

(2004)

Baeyens et al (2005b)

Mozdarani et al (2005)

Breast cancer patients:

52 with family history

II BRCA

9 BRCA2

6 BRCAI

6 BRCA2

Relatives without mutation:

5 BRCAI

5 BRCA2

Age 45 (10) range (29-69)

$42-43$

86 unselected breast cancer patients, sampling was carried out before surgery and chemotherapy

Age $5 \mathrm{I}(\mathrm{I}$ ) range $(3 \mathrm{I}-77)$

50 unselected breast cancer patients (I man and 49 women)

\section{Controls}

42 normal volunteers ( 28

women and 14 men)

Age 47.8 (13.4) range (23-72)

(23-72)

68 healthy subjects

Age 45 range (22-72)

68 healthy subjects historical controls from Scott et al (1999)

MN assay

Whole blood

PHA 6h after irradiation

Harvesting $90 \mathrm{~h}$

Slides stained with Giemsa

Visual counting

100 BNCs/slide

Whole blood

PHA $6 \mathrm{~h}$ after irradiation

Harvesting $90 \mathrm{~h}$

Slides stained with Giemsa

Visual counting

$100 \mathrm{BNCs} /$ slide

Whole blood

PHA $6 \mathrm{~h}$ after irradiation

Harvesting $90 \mathrm{~h}$

Slides stained with Giemsa

Visual counting

$100 \mathrm{BNCs} /$ slide

17 age-matched women without any family history of cancer

Age 36 (9) range 25-53

14 women without any family history of cancer

13 women without any family
history of cancer

history of cancer

48 healthy women

Age 46 (9.8) range

$(23-60)$

Relatives with mutation Without any exposure to chemotherapy or radiotherapy before sampling

Age 46.9 ( 11.4$)$ range $(25-78)$

All no smokers

Whole blood

Harvesting $68 \mathrm{~h}$ orange

Visual counting

1000 BNCs/slide

Whole blood

Harvesting $68 \mathrm{~h}$ orange

Visual counting

1000 BNCs/slide

Whole blood

Harvesting $68 \mathrm{~h}$ orange

Visual counting

1000 BNCs/slide

Whole blood

Harvesting $70 \mathrm{~h}$

Visual counting

Total 1000 BNCs
Whole blood

Harvesting $70 \mathrm{~h}$

Slides stained with Giemsa

Visual counting

$1000 \mathrm{BNCs} /$ subject

Whole blood

Harvesting $90 \mathrm{~h}$

Slides stained with Giemsa

Visual counting

1000 BNCs/slide

\section{Treatment}

Gamma rays source: 137

Cs total dose $3.5 \mathrm{~Gy}$

HDR dose rate I Gy min ${ }^{-1}$

LDR dose rate

0.15 cGy min $^{-1}$

Gamma rays source:137Cs total dose $3.5 \mathrm{~Gy}$ HDR dose rate I Gy min ${ }^{-1}$

Gamma rays source: 137 Cs total dose $3.5 \mathrm{~Gy}$ HDR dose rate I Gy min ${ }^{-1}$

Gamma rays source: cobalt-60 total dose $2 \mathrm{~Gy}$

Slides stained with acridine HDR dose rate $4 \mathrm{~Gy} \mathrm{~min}^{-1}$

Gamma rays source cobalt-

Slides stained with acridine HDR dose rate 4 Gy $\mathrm{min}^{-1}$

Gamma rays source cobalt-

Slides stained with acridine HDR dose rate $4 \mathrm{~Gy} \mathrm{~min}{ }^{-1}$

$x$ rays

57 healthy women

Age $37(12)$ range

(29-69)

Whole blood

Harvesting $70 \mathrm{~h}$

Slides stained with Giemsa

Visual counting

1000 BNCs/subject

Gamma rays source cobalt60 total dose $2 \mathrm{~Gy}$

HDRI Gy min ${ }^{-1}$ total dose

$3.5 \mathrm{~Gy}$

HDR I Gy min ${ }^{-1}$

Total dose $3.5 \mathrm{~Gy}$

LDR; 4 mGy min

84 normal healthy women

73 concurrent control

Age 30 (7) range 24-58

40 normal healthy subjects

( 13 men and 27 women)

Age 38.I (9.4) range

(24-62)

All no smokers
Gamma rays source cobalt60 total dose $3.5 \mathrm{~Gy}$

LDR; 4 mGy min $^{-1}$

Gamma rays source cobalt60 total dose $3 \mathrm{~Gy}$

HDR dose rate

$70 \mathrm{cGy} \mathrm{min}^{-1}$ 
Table I (Continued)

\begin{tabular}{|c|c|c|c|c|c|}
\hline Reference & $\begin{array}{c}\text { Contrast } \mathbf{N} \\
\text { in Table } 2\end{array}$ & Cases & Controls & $M N$ assay & Treatment \\
\hline $\begin{array}{l}\text { Varga et al } \\
(2006)\end{array}$ & $45-50$ & $\begin{array}{l}\text { Sample A: } \\
85 \text { sporadic breast cancer } \\
6 \text { carriers of BRCAI mut } \\
47 \text { between diagnosis and start of the } \\
\text { therapy or when therapy had been } \\
\text { finished for at least } 3 \text { months } \\
33 \text { without therapy } \\
\text { Age } 56.7 \text { range }(35-80) \\
32 \text { sporadic cancers (subgroup) } \\
\text { Age } 56.6 \text { range ( } 37-80) \\
\text { Sample B: } \\
20 \text { sporadic breast cancer } \\
\text { patients } \\
\text { Age } 44.4 \text { range }(23-68)\end{array}$ & $\begin{array}{l}\text { Sample A: } \\
96 \text { female controls } \\
\text { hospital healthy patients } \\
\text { non-blood relatives of the } \\
\text { patients and occasional controls } \\
\text { Age } 42.7 \text { range }(20-90) \\
21 \text { controls (subgroup) } \\
\text { age } 40.5 \text { range ( } 23-68) \\
\text { Sample B: } \\
21 \text { hospital healthy patients } \\
\text { (recruited in another hospital) } \\
\text { Age } 58.0 \text { range }(29-81)\end{array}$ & $\begin{array}{l}\text { Whole blood culture } \\
\text { Harvesting } 72 \mathrm{~h} \\
\text { Slides stained with Giemsa } \\
\text { Visual counting } \\
500-1000 \text { BNCs } \\
\text { Automated counting } \\
\text { (DAPI) } 500 \text { BNCs; } \\
\text { reanalysis } \\
\text { Automated counting } \\
\text { (DAPI) } \\
500 \text { BNCs }\end{array}$ & $\begin{array}{l}\text { Gamma rays source: } 137 \\
\text { CS total dose } 2 \text { Gy } \\
\text { HDR dose rate } 4 \text { Gy min }\end{array}$ \\
\hline $\begin{array}{l}\text { Kotsopoulos et al } \\
\text { (2007) }\end{array}$ & 51 & $\begin{array}{l}25 \text { cancer-free female heterozygous } \\
\text { BRCAI mutation carriers } \\
\text { Age } 43.56(9.81) \text { range }(20-60)\end{array}$ & $\begin{array}{l}25 \text { healthy mutation-negative } \\
\text { females from the same } \\
\text { families as the cases } \\
\text { Age } 44.62(11.19) \text { range } \\
(20-60)\end{array}$ & $\begin{array}{l}\text { Isolated lymphocytes } \\
\text { Irradiated } 24 \mathrm{~h} \text { after the } \\
\text { culture set up } \\
\text { Harvesting } 68 \mathrm{~h} \\
\text { Slides stained with acridine } \\
\text { orange } \\
\text { Visual counting } \\
200 \text { BNCs }\end{array}$ & $\begin{array}{l}\text { Gamma rays source: } 137 \\
\text { CS total dose } 2 \mathrm{~Gy} \\
\text { HDR } 1.07 \mathrm{~Gy} \mathrm{~min}^{-1}\end{array}$ \\
\hline
\end{tabular}

Abbreviations: $\mathrm{BNCs}=$ binucleated cells; $\mathrm{DAPI}=4$ ',6-diamidino-2-phenylindole; $\mathrm{HDR}=$ high-dose rate; $\mathrm{LDR}=\mathrm{low}$-dose rate; $\mathrm{MN}=$ micronuclei; $\mathrm{Neg}=$ negative; $\mathrm{PHA}=$ phytohemoagglutinin.

subjects with BC and healthy controls (Figure 2A). Twelve contrasts were in FH-negative and four in $\mathrm{FH}$-positive cases. In all studies, $\mathrm{MN}$ frequency was higher in cases than in controls. Overall, there was a difference of $14.2 \mathrm{MN} / 1000$ (s.e. 2.4; 95\% CL 9.3-19.1; $P<0.001$ ) between BC patients and controls (subjects without cancer, BRCA negatives and with negative $\mathrm{FH}$ for $\mathrm{BC}$ ).

The difference was similar in FH-negative subjects (WMD 13.6; s.e. 3.3; 95\% CL 7.1-20.2; $P<0.001)$ and in FH-positive subjects (WMD 16.1; s.e. $2.7 ; 95 \%$ CL $10.7-21.5 ; P<0.001$ ). The difference between means of the two subgroups was not significant (Student's $t$-test $P=0.684$ ), suggesting that the increase in $\mathrm{MN}$ frequency was due solely to the presence of cancer (Figure 2A).

The difference between $\mathrm{BC}$ cases and controls in $\mathrm{MN}$ frequency after irradiation of the cell culture was evaluated in 25 contrasts; 15 in FH-negative subjects and 10 in FH-positive subjects (Figure 2B). Again, MN frequency was higher in $\mathrm{BC}$ cases than in controls in all contrasts, for a summary WMD of 71.7 (s.e. $=8.8,95 \%$ CL 54.1 89.3; $P<0.001)$. The increase observed in FH-positive subjects (WMD 82.2; s.e. 13.7; 95\% CL 54.8-109.58; $P<0.001$ ) compared with that observed in FH-negative subjects (WMD 64.3; s.e.=11.3; 95\% CL 41.6-87.1; $P<0.001$ ) could suggest a possible effect of hereditary/familial factors, but the difference between the two WMD's groups was not significant (Student's $t$-test $P=0.325$ ).

FH positive vs negative There were 14 contrasts available to assess the difference in the baseline $\mathrm{MN}$ frequency between subjects with positive and negative $\mathrm{FH}$ (Figure $3 \mathrm{~A}$ ). Ten contrasts were in tumournegative subjects (with five contrasts excluded because of missing information on s.e.) and four in tumour-positive subjects. In all studies, MN frequency was higher in cases than in controls. Overall, there was a difference of $13.2 \mathrm{MN} / 1000$ (s.e. 2.0; 95\% CL 9.2-17.2; $P<0.001)$ between positive $\mathrm{FH}$ subjects and controls.

At baseline, the difference between $\mathrm{FH}$ positive and $\mathrm{FH}$ negative was higher in tumour-positive subjects (WMD 16.1; s.e. 2.6; $95 \%$ CL $10.8-21.5 ; P<0.001$ ) than in tumour-negative subjects (WMD 11.0 ; s.e. $2.6 ; 95 \%$ CL $5.8-16.2 ; P<0.001)$. The increment in $\mathrm{MN}$ frequency in the tumour-positive subjects could suggest an independent effect of the two factors, (Figure 3A) although the Student's $t$-test $(P=0.213)$ is not significant.
The difference in $\mathrm{MN}$ frequency after irradiation of the cell culture between subjects with positive and negative $\mathrm{FH}$ was evaluated in 29 contrasts; 19 in tumour-negative subjects (with 3 contrasts excluded because of missing information on s.e.) and 10 in tumour-positive subjects (Figure $3 \mathrm{~B}$ ). MN frequency was higher in subjects with positive $\mathrm{FH}$ than in controls in 24 contrasts and lower in 5 , for a summary WMD of 64.3 (s.e. $=12.9 ; 95 \%$ CL $38.6-90.0 ; P<0.001)$. The increase observed in tumour-positive subjects (WMD 82.2; s.e. 13.8; 95\% CL 54.8-109.5; $P<0.001$ ) compared with that observed in tumour-negative subjects (WMD 49.4; s.e. 20.3 ; $95 \%$ CL 9.2-89.7; $P=0.016$ ), could suggest a more marked effect of the cancer patient status, but the difference between the two WMD's was not significant (Student's $t$-test $P=0.253$ ).

Role of BRCA There were 14 contrasts available to assess the difference in the baseline MN frequency between subjects with positive $\mathrm{FH}$ in whom BRCA status was assessed and healthy controls (Figure 4A).

Three contrasts were in BRCA negative - tumour-negative subjects (with one contrast excluded because of missing information on s.e.); one contrast in BRCA negative - tumour-positive subjects; seven in BRCA positive - tumour-negative subjects (with four contrasts excluded because of missing information on s.e.) and three contrasts in BRCA positive - tumour-positive subjects.

In all studies, $\mathrm{MN}$ frequency was higher in cases than in controls.

Overall, in the BRCA-negative group, there was a difference of 13.3 MN/1000 (s.e. 2.8; 95\% CL 7.8-18.8, $P<0.001$ ) between BRCA-negative patients with $\mathrm{FH}$ positive and controls. In the BRCA-positive group, the difference was almost identical; 13.1 $\mathrm{MN} / 1000$ (s.e. 2.9 ; 95\% CL 7.2-18.9, $P<0.001$ ) between BRCApositive patients with $\mathrm{FH}$ positive and controls (subjects without cancer, BRCA negative and with a negative $\mathrm{FH}$ for $\mathrm{BC}$ ).

At baseline, when the effect of BRCA status on MN frequency was stratified according to $\mathrm{BC}$ status, no noteworthy variations was seen; in fact, the difference was similar in BRCA negative tumour-negative subjects (WMD 10.6; s.e. 3.7; 95\% CL 3.4-17.8; $P=0.004)$ and in BRCA positive - tumour-negative subjects (WMD 11.4; s.e. 4.4; 95\% CL 2.5-20.3; $P=0.012$ ). 
Table 2 List of contrasts in individual studies

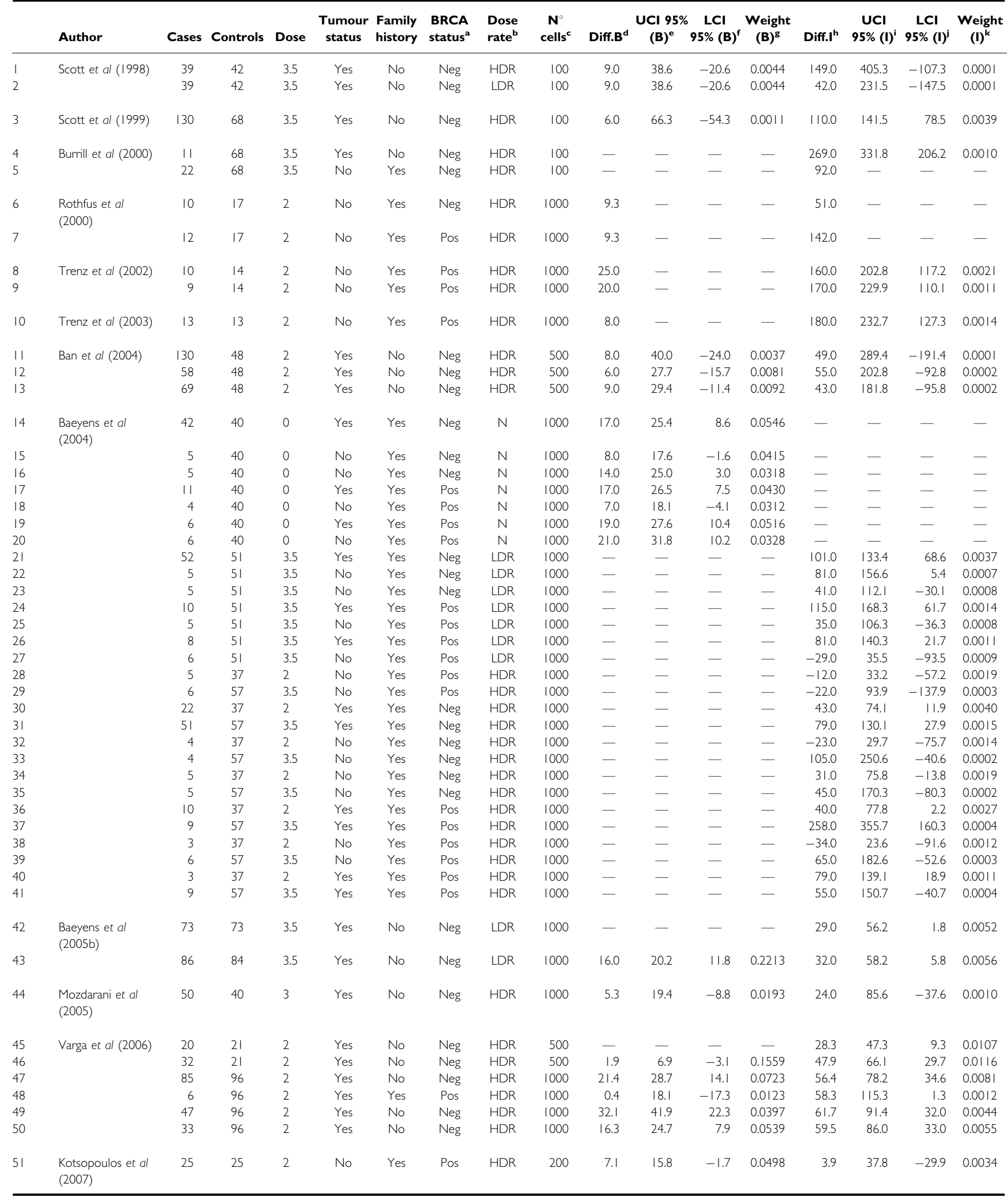

Abbreviations: $\mathrm{HDR}=$ high-dose rate; $\mathrm{LCl}=$ lower confidence interval; $\mathrm{LDR}=$ low-dose rate; $\mathrm{Neg}=$ negative; $\mathrm{Pos}=$ positive; $\mathrm{UCl}=$ upper confidence interval. ${ }^{a} \mathrm{Negative}$ if BRCA is negative for BRCAI or 2, and positive if BRCA is positive for BRCA I or 2. ${ }^{\mathrm{b} H D R}$ or LDR. ${ }^{\circ}$ Number cells analysed. ${ }^{\mathrm{d}}$ Difference between cases and controls at baseline. ${ }^{\mathrm{e}} \mathrm{UCl}$ at baseline. ${ }^{\mathrm{f}} \mathrm{LCl}$ at baseline. ${ }^{\mathrm{g}} \mathrm{W}$ eight at baseline. ${ }^{\mathrm{h}} \mathrm{Difference}$ between cases and controls after irradiation. ${ }^{\mathrm{U}} \mathrm{UCl}$ after irradiation. ${ }^{\mathrm{j}} \mathrm{LCl}$ after irradiation. ${ }^{\mathrm{k}} \mathrm{Weight}$ after irradiation. 
A

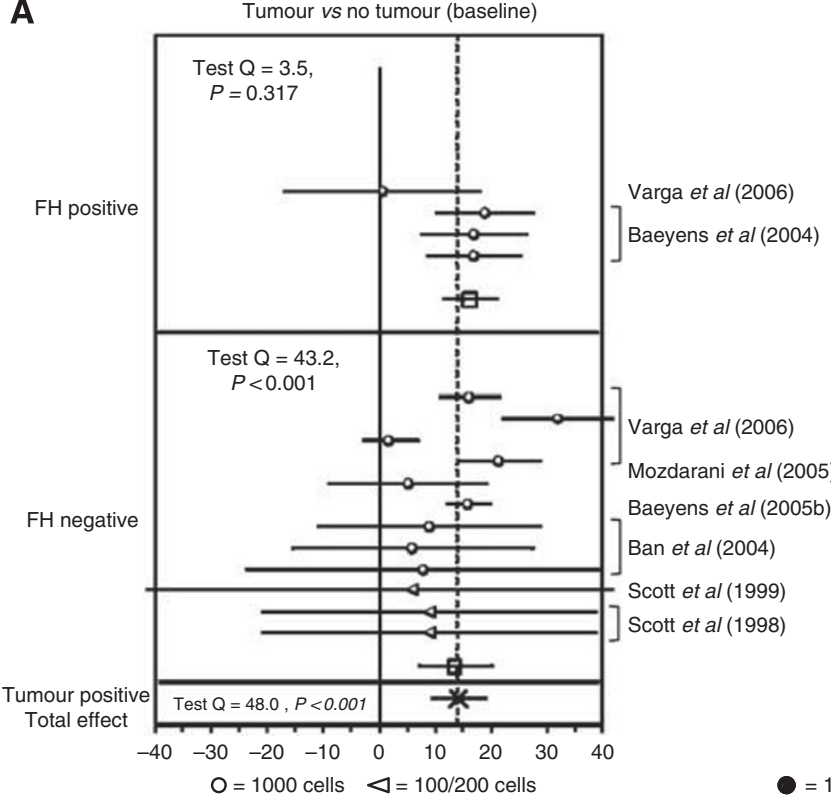

B

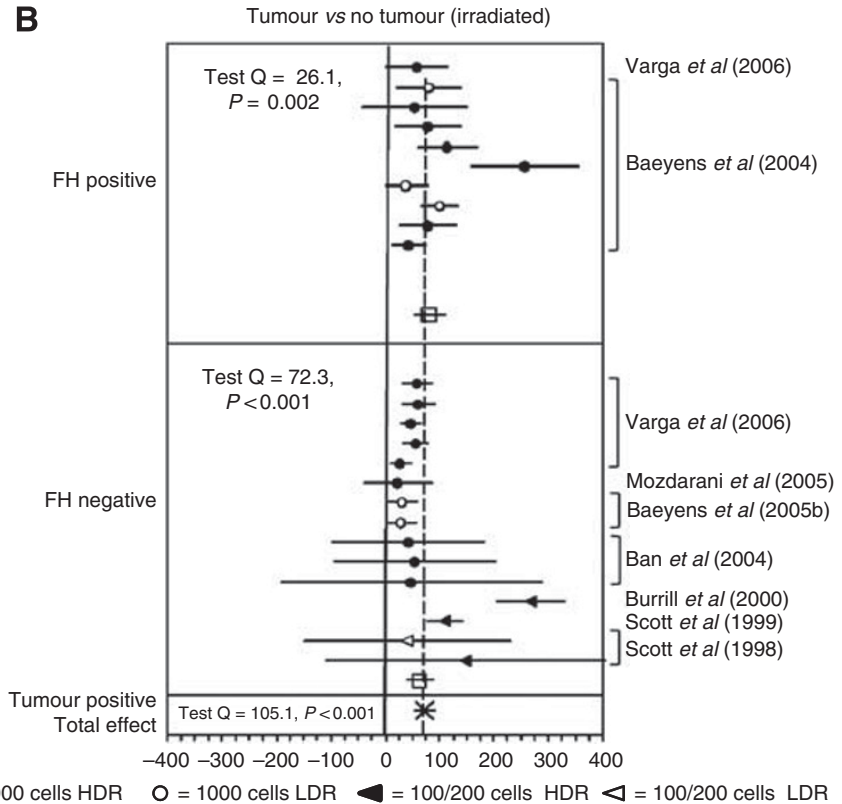

Summary estimates of difference stratified by FH status (baseline)

\begin{tabular}{|l|c|c|c|}
\hline & $\begin{array}{c}\text { Family history } \\
\text { negative }\end{array}$ & $\begin{array}{c}\text { Family history } \\
\text { positive }\end{array}$ & $\begin{array}{c}\text { Tumour } \\
\text { positive } \\
\text { total effect }\end{array}$ \\
\hline WMD & 13.6 & 16.1 & 14.2 \\
\hline s.e. & 3.3 & 2.7 & 2.4 \\
\hline IC $95 \%$ & $7.1 / 20.2$ & $10.7 / 21.5$ & $9.3 / 19.1$ \\
\hline$Z$ value & 4.07 & 5.88 & 5.66 \\
\hline$P$ value & $<0.001$ & $<0.001$ & $<0.001$ \\
\hline & \multicolumn{2}{|c|}{$\begin{array}{r}\text { Comparison of WMD in } \mathrm{FH}-\text { and } \mathrm{FH}+ \\
\text { status. } P=0.684\end{array}$} \\
\hline
\end{tabular}

Summary estimates of difference stratified by FH status (irradiated)

\begin{tabular}{|c|c|c|c|}
\hline & $\begin{array}{l}\text { Family history } \\
\text { negative }\end{array}$ & $\begin{array}{l}\text { Family history } \\
\text { positive }\end{array}$ & $\begin{array}{c}\text { Tumour } \\
\text { positive } \\
\text { total effect }\end{array}$ \\
\hline WMD & 64.3 & 82.2 & 71.7 \\
\hline s.e. & 11.3 & 13.7 & 8.8 \\
\hline IC $95 \%$ & $41.6 / 87.1$ & $54.8 / 109.5$ & $54.1 / 89.3$ \\
\hline$Z$ value & 5.54 & 5.90 & 7.98 \\
\hline$P$ value & $<0.001$ & $<0.001$ & $<0.001$ \\
\hline & \multicolumn{2}{|c|}{$\begin{array}{c}\text { Comparison of WMD in } \mathrm{FH}-\text { and } \mathrm{FH}+ \\
\text { status. } P=0.325\end{array}$} & \\
\hline
\end{tabular}

Figure 2 (A and $\mathbf{B}$ ) Forest plot of the differences in the baseline and induced $M N$ frequency between subjects with breast cancer and healthy controls. Studies are plotted in order of publication. Each circle represents the difference between cases and controls. Horizontal lines corresponds to $95 \%$ Cl. The square symbolises the WMD (weighted mean difference) for each subgroup.

Also in subjects with $\mathrm{BC}$, the difference between cases and controls was similar in BRCA-positive (WMD 14.9; s.e. 4.2; 95\% CL $6.5-23.3 ; P=0.001$ ) and BRCA-negative subjects (WMD 17.0; s.e. 4.3 ; 95\% CL 8.6-25.4; $P<0.001$ ).

There were 28 contrasts available to assess the difference in the $\mathrm{MN}$ frequency, after irradiation of the cell culture, between subjects with positive $\mathrm{FH}$, in whom BRCA status had been assessed, and healthy controls. Seven contrasts were in BRCA negative - tumournegative subjects (with 1 contrast excluded because of missing information on s.e.); 3 in BRCA negative - tumour-positive subjects; 11 in BRCA positive - tumour-negative subjects (with 1 contrast excluded because of missing information on s.e.) and 7 in BRCA positive - tumour-positive subjects (Figure 4B).

In all contrasts but five, $\mathrm{MN}$ frequency was higher in cases than in controls. Overall, in the BRCA-negative group, there was a difference of $52.8 \mathrm{MN} / 1000$ (s.e. 14.6; 95\% CL 23.8-81.8; $P<0.001$ ) between negative BRCA patients with $\mathrm{FH}$ positive and controls (subjects without cancer, BRCA negatives and with negative $\mathrm{FH}$ for $\mathrm{BC}$ ).

In the entire BRCA-positive group, there was a similar difference of $70.3 \mathrm{MN} / 1000$ (s.e. 18.9 ; 95\% CL $32.8-107.9, P<0.001$ ) between positive BRCA patients with $\mathrm{FH}$ positive and controls (subjects without cancer, BRCA negatives and with negative FH for BC).

The role of BRCA status was then evaluated after stratification for the presence/absence of $\mathrm{BC}$. In $\mathrm{BC}$ patients, the difference between cases and controls was very similar in BRCA-negative subjects (WMD 73.6; s.e. 10.5; 95\% CL 34.9-112.2; $P<0.001$ ) and in BRCA-positive subjects (WMD 89.9; s.e. 20.9; 95\% CL 48.5131.3; $P<0.001)$. There is no significant difference between the WMD of the two groups (Student's $t$-test $P=0.641$ ).
Conversely the increase observed in BRCA positive - tumournegative subjects (WMD 53.5; s.e. $29.2 ; 95 \%$ CL $-4.4-111.4$; $P=0.007)$ was almost twice as large as that in BRCA negative tumour-negative subjects (WMD 31.3; s.e. 17.1; 95\% CL -2.6$65.3 ; P=0.071)$. This could suggest an effect of BRCA on MN frequency, but again, the difference between the two WMD was not significant (Student's $t$-test $P=0.590$ ).

\section{DISCUSSION}

The MNT has been widely applied to evaluate the chromosomal instability in selected groups of patients affected by cancer or degenerative diseases, compared with control, healthy populations (Andreassi et al, 2011; Bonassi et al, 2011; El-Zein et al, 2011; Migliore et al, 2011). Furthermore, the induced MN frequency, as expression of mutagen sensitivity, was viewed as a possible means to predict the $\mathrm{BC}$ risk at the individual level in the light of the link between deficient repair of DNA and genetic predisposition to BC. Known BC susceptibility genes such as BRCA1, BRCA2, ATM, CHK2 and TP53 are involved in maintaining the genomic stability through their involvement in DNA double-strand break repair, transcription-coupled repair and homologous recombination; defects in their expression are expected to lead to an increased mutagen sensitivity as expression of an intermediate phenotype in cancer development (Venkitaraman, 2002, 2009; Smith et al, 2003; Hsu et al, 2007; Ralhan et al, 2007; Couch and Wang, 2009; Kwei et al, 2010; Latimer et al, 2010).

Many studies are available in the literature on the application of MNT, evaluated as baseline level (Iarmarcovai et al, 2008; Bonassi 
A Family history positive vs family history negative (baseline)

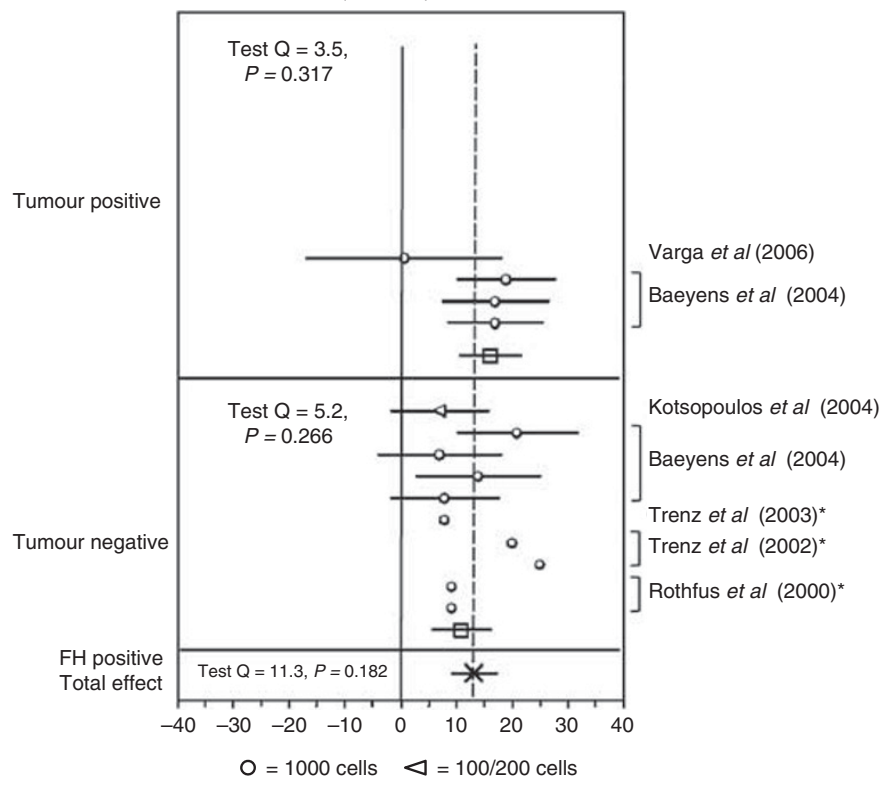

Summary estimates of difference stratified by tumour status (baseline)

\begin{tabular}{|l|c|c|c|}
\hline & Tumour negative & Tumour positive & $\begin{array}{c}\text { Family history } \\
\text { positive } \\
\text { total effect }\end{array}$ \\
\hline WMD & 11.0 & 16.1 & 13.2 \\
\hline s.e. & 2.6 & 2.6 & 2.0 \\
\hline IC $95 \%$ & $5.8 / 16.2$ & $10.8 / 21.5$ & $9.2 / 17.2$ \\
\hline$Z$ value & 4.15 & 5.88 & 6.47 \\
\hline$P$ value & $<0.001$ & $<0.001$ & $<0.001$ \\
\hline & \multicolumn{2}{|c|}{$\begin{array}{c}\text { Comparison of WMD in tumour - and } \\
\text { tumour + status. } P=0.213\end{array}$} \\
\hline
\end{tabular}

${ }^{*}$ s.e. not provided . not included in summary estimates

\section{B}

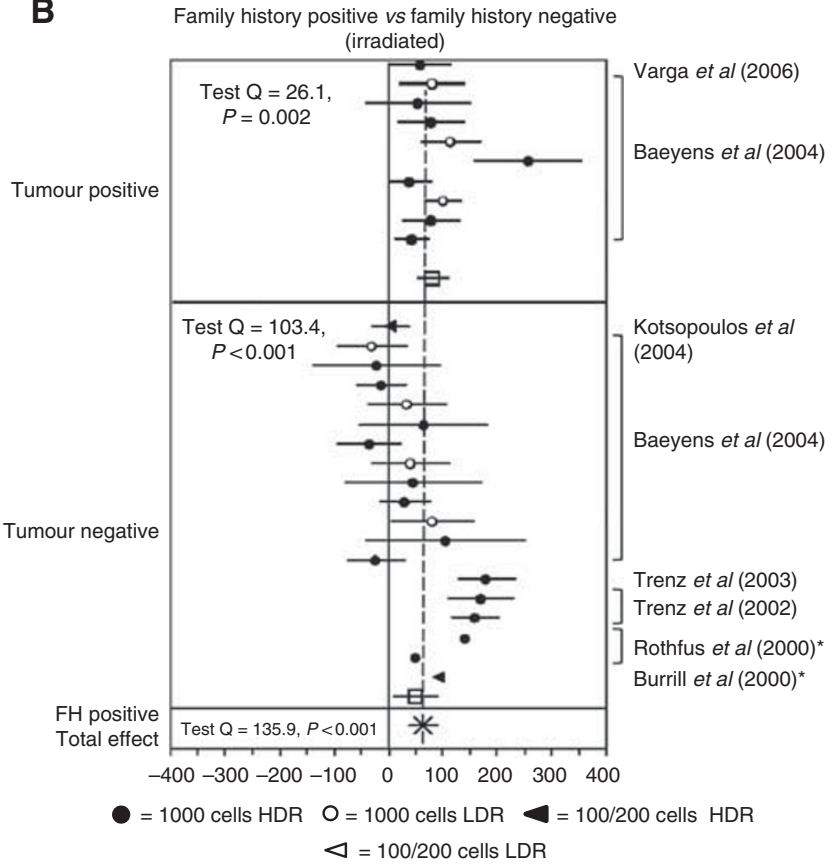

Summary estimates of difference stratified by tumour status (irradiated)

\begin{tabular}{|l|c|c|c|}
\hline & Tumour negative & Tumour positive & $\begin{array}{c}\text { Family history } \\
\text { positive } \\
\text { total effect }\end{array}$ \\
\hline WMD & 49.4 & 82.2 & 64.3 \\
\hline s.e. & 20.3 & 13.8 & 12.9 \\
\hline IC 95\% & $9.2 / 89.7$ & $54.8 / 109.5$ & $38.6 / 90.0$ \\
\hline$Z$ value & 2.41 & 5.90 & 4.91 \\
\hline$P$ value & 0.016 & $<0.001$ & $<0.001$ \\
\hline \multicolumn{3}{|c|}{$\begin{array}{c}\text { Comparison of WMD in tumour - and } \\
\text { tumour + status. } P=0.253\end{array}$} \\
\hline \multicolumn{3}{|c|}{ * s.e. not provided not included in summary estimates }
\end{tabular}

Figure 3 (A and B) Forest plot of the differences in the baseline and induced MN frequency between subjects with a FH for BC and healthy controls. Studies are plotted in order of publication. Each circle represents the difference between cases and controls. Horizontal lines corresponds to $95 \% \mathrm{Cl}$. The square symbolises the WMD (weighted mean difference) for each subgroup.

et al, 2011) and after in vitro challenge, involving more than 1000 cases of $\mathrm{BC}$ patients and subjects with known or putative cancer predisposition. An association between $\mathrm{MN}$ induction and $\mathrm{BC}$ development was reported in the large majority of studies showing an increased baseline $\mathrm{MN}$ frequency in untreated cancer patients. Enhanced in-vitro mutagen sensitivity, revealed by the MN assay, in $\mathrm{BC}$ patients compared with healthy controls is also a common finding with large variability among studies, whereas contrasting results were obtained in subjects with $\mathrm{FH}$. Few studies involving small groups of subjects show increased mutagen sensitivity in irradiated peripheral lymphocytes of BRCA1/2 mutation carriers compared with healthy controls, but the implication of the BRCA mutation was not appreciable in other studies when the comparison was made with BC patients without a BRCA mutation, suggesting a major role of cancer status in mutagen sensitivity.

Overall, despite numerous studies showing the enhanced chromosomal damage as a cancer predisposition factor, the role of MNT in predicting BC risk is still not clear.

The main reasons for that are the inadequacy of the study design, the inconsistency in subject recruitment and classification, and the small size of most studies.

Our systematic review, focusing on investigations involving the in vitro challenge, selected 12 studies eligible for the meta-analysis. These studies, published between 1998 and 2007, are very heterogeneous in many respects. First, tumour status, FH and BRCA status were not homogenously characterised. Cancer patients were categorised as unselected or sporadic. The criteria applied to define the FH were different, including in some cases an early onset of cancer and in one case, previous data on radiation sensitivity. BRCA-positive cases include cancer patients and their relatives carrying different BRCA1 or BRCA2 mutations.

A second factor that was not consistently considered in the different studies is the exposure to genotoxic agents, antiblastic drugs or radiations, for therapy or diagnostic purposes. The chromosomal damage associated to these treatments could last long time after the exposure, affecting the baseline MN frequency and potentially modulating the responses to the challenge agent in vitro. The data available on patients who received a cytostatic therapy show that persistent DNA damage in lymphocytes before culture can be expressed as $\mathrm{MN}$ during the in-vitro cell proliferation. A large variability in the persistence of chromosomal damage after a chemotherapeutic treatment was described, related to the kind of drug, the period of treatment and the individual response (Arsoy et al, 2009).

Finally, the experimental protocols applied in the selected studies were heterogeneous; different criteria of MN scoring were used, the conditions of in-vitro irradiation included different doses and low- and high-irradiation rate. All these factors increase the variability within and among the studies.

Despite all these factors potentially impairing this meta-analysis, our review indicates that the chromosomal mutagen sensitivity, measured as $\mathrm{MN}$ frequency, is a common feature of cells from BC 
A

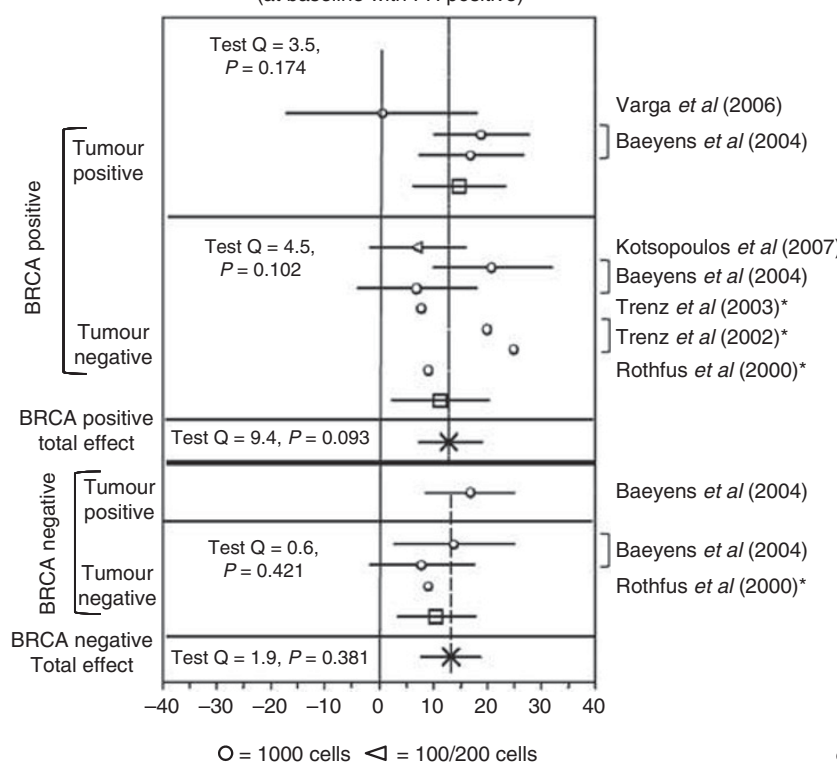

Summary estimates of difference stratified by BRCA and tumour status (baseline)

\begin{tabular}{|c|c|c|c|c|c|c|}
\hline & $\begin{array}{l}\text { Tumour } \\
\text { negative }\end{array}$ & $\begin{array}{l}\text { Tumour } \\
\text { positive }\end{array}$ & $\begin{array}{c}\text { BRCA } \\
\text { negative } \\
\text { total } \\
\text { effect }\end{array}$ & $\begin{array}{l}\text { Tumour } \\
\text { negative }\end{array}$ & $\begin{array}{l}\text { Tumour } \\
\text { positive }\end{array}$ & $\begin{array}{c}\text { BRCA } \\
\text { positive } \\
\text { total } \\
\text { effect }\end{array}$ \\
\hline$\overline{\text { WMD }}$ & 10.6 & 17.0 & 13.3 & 11.4 & 14.9 & 13.1 \\
\hline s.e. & 3.7 & 4.3 & 2.8 & 4.4 & 4.2 & 2.9 \\
\hline IC 95\% & $3.4 / 17.8$ & $8.6 / 25.4$ & $7.8 / 18.8$ & $2.5 / 20.3$ & $6.5 / 23.3$ & $7.2 / 18.9$ \\
\hline$Z$ value & 2.87 & 3.97 & 4.76 & 2.52 & 3.46 & 4.35 \\
\hline$P$ value & 0.004 & $<0.001$ & $<0.001$ & 0.012 & 0.001 & $<0.001$ \\
\hline & \multicolumn{2}{|c|}{$\begin{array}{c}\text { Comparison of } \\
\text { WMD. } P=0.212\end{array}$} & & \multicolumn{2}{|c|}{$\begin{array}{c}\text { Comparison of } \\
\text { WMD. } P=0.595\end{array}$} & \\
\hline
\end{tabular}

${ }^{*}$ s.e. not provided. Not included in summary estimates
B

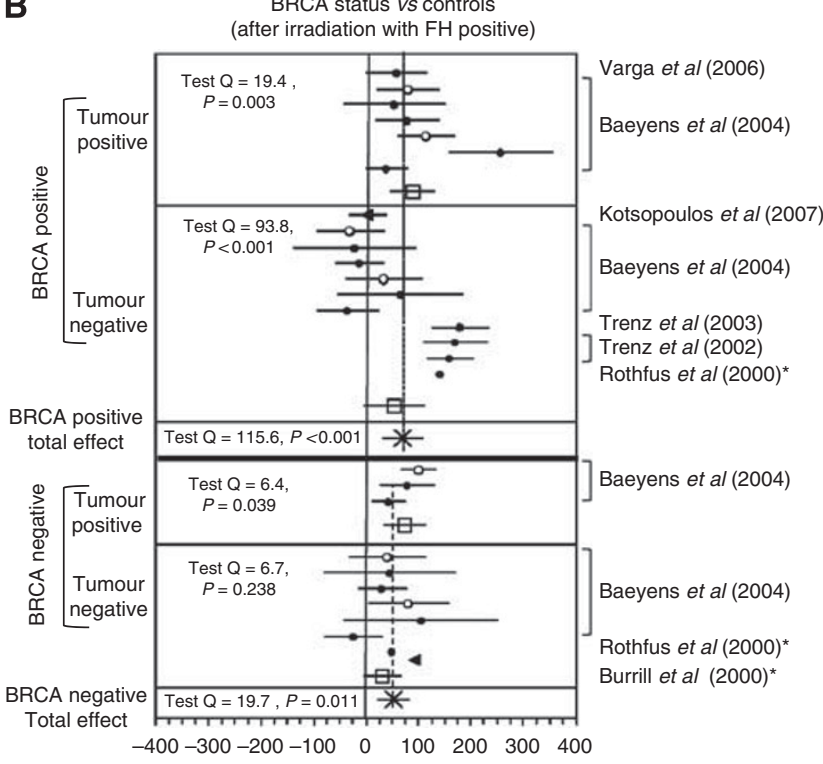

$=1000$ cells HDR $\quad O=1000$ cells LDR $\square=100 / 200$ cells HDR $\triangleleft=100 / 200$ cells LDR

Summary estimates of difference stratified by BRCA and tumour status (irradiated)

\begin{tabular}{|l|c|c|c|c|c|c|}
\hline & $\begin{array}{c}\text { Tumour } \\
\text { negative }\end{array}$ & $\begin{array}{c}\text { Tumour } \\
\text { positive }\end{array}$ & $\begin{array}{c}\text { BRCA } \\
\text { negative } \\
\text { total } \\
\text { effect }\end{array}$ & $\begin{array}{c}\text { Tumour } \\
\text { negative }\end{array}$ & $\begin{array}{c}\text { Tumour } \\
\text { positive }\end{array}$ & $\begin{array}{c}\text { BRCA } \\
\text { positive } \\
\text { total } \\
\text { effect }\end{array}$ \\
\hline WMD & 31.3 & 73.6 & 52.8 & 53.5 & 89.9 & 70.3 \\
\hline s.e. & 17.1 & 10.5 & 14.6 & 29.2 & 20.9 & 18.9 \\
\hline IC 95\% & $-2.6 / 65.3$ & $34.9 / 112.2$ & $23.8 / 81.8$ & $-4.4 / 111.4$ & $48.5 / 131.3$ & $32.8 / 107.9$ \\
\hline$Z$ value & 1.80 & 3.73 & 3.56 & 1.81 & 4.26 & 3.67 \\
\hline$P$ value & 0.071 & $<0.001$ & $<0.001$ & 0.007 & $<0.001$ & $<0.001$ \\
\hline & $\begin{array}{c}\text { Comparison of WMD } \\
P=0.147\end{array}$ & & $\begin{array}{c}\text { Comparison of WMD } \\
P=0.368\end{array}$ & \\
\hline
\end{tabular}

${ }^{*}$ s.e. not provided . Not included in summary estimates

Figure 4 (A and B) Forest plot of the differences in the baseline and induced MN frequency between BRCAI/2 mutation carriers and healthy controls. Studies are plotted in order of publication. Each circle represents the difference between cases and controls. Horizontal lines corresponds to $95 \%$ Cl. The square symbolises the WMD (weighted mean difference) for each subgroup.

patients, but it is not clearly associated with FH and specifically with BRCA mutations. A significantly increased baseline MN frequency was observed in more than $700 \mathrm{BC}$ patients pooled from the different studies, when compared with healthy controls. Conversely, the role of the genetic predisposition to $\mathrm{BC}$ could not be demonstrated in a smaller and more heterogeneous pool of 201 subjects characterised by a cancer $\mathrm{FH}$, including cancer patients and healthy subjects. Higher difference in $\mathrm{MN}$ frequency was observed in the subgroup of cancer patients than in healthy subjects, confirming cancer status as the main determinant. The available studies on BRCA 1 and 2 mutation carriers involved small groups of subjects and reported contrasting results; our meta-analysis including 117 cases, pooled from different studies, shows similar difference between cases and controls in BRCApositive cases and in cases with a negative BRCA test.

A large difference between cases and controls was detected in all subgroups, using the challenge assay. However, this approach did not appear to improve the possibility to identify cancer-susceptible subjects on the basis of the response to radiation exposure; the differences between cases and controls was not significantly increased in family positive and BRCA positive as compared with family negative and BRCA negative.

The results of our analysis, far from being conclusive, suggest the need of further well-designed studies to define the role of MNT and the advantage of using in-vitro challenge in predicting individual $\mathrm{BC}$ risk. Of the various factors highlighted by our meta-analysis, as relevant in designing new studies, the most important ones are the procedures for the recruitment of study subjects and the characterisation of cases and controls. Other factors contributing to the difference in test performance among the studies are related to the use of different experimental protocols and criteria of scoring. The use of a standardised protocol and the intercalibration of the MN scoring among the labs in multicentric studies, needed to recruit adequate groups of cases, could allow to reduce the test variability. In addition, the perspective to apply the automated scoring of MN (Varga et al, 2004; Decodier et al, 2009; Willems et al, 2010; Bolognesi et al, 2011) could allow to evaluate large number of cultures and cells allowing to minimise the experimental variability and to define more reliable individual MN frequency values.

In summary, the systematic difference in $\mathrm{MN}$ frequency between cases and controls, in the large majority of contrasts, not attributable to any of the factors under study, suggests the presence of some bias affecting many of these studies, thus reinforcing the suggestion that more rigorous study designs are needed in this area.

\section{ACKNOWLEDGEMENTS}

This work was in part supported by the Italian Association for Research on Cancer (AIRC) (Project IG 5706 2008). 


\section{REFERENCES}

Albertini RJ, Anderson D, Douglas GR, Hagmar L, Hemminki K, Merlo F, Natarajan AT, Norppa H, Shuker DE, Tice R, Waters MD, Aitio A (2000) IPCS guidelines for the monitoring of genotoxic effects of carcinogens in humans. International Programme on Chemical Safety. Mutat Res 463: $111-172$

Andreassi MG, Barale R, Iozzo P, Picano E (2011) The association of micronucleus frequency with obesity, diabetes and cardiovascular disease. Mutagenesis 26: $77-83$

Arsoy NS, Neuss S, Wessendorf S, Bommer M, Viardot A, Schutz P, Speit G (2009) Micronuclei in peripheral blood from patients after cytostatic therapy mainly arise ex vivo from persistent damage. Mutagenesis 24: $351-357$

Baeyens A, Claes K, Willems P, De Ruyck K, Thierens H, Vral A (2005a) Chromosomal radiosensitivity of breast cancer with a CHEK2 mutation. Cancer Gen Cytogen 163: 106-112

Baeyens A, Thierens H, Claes K, Poppe B, de Ridder L, Vral A (2004) Chromosomal radiosensitivity in BRCA1 and BRCA2 mutation carriers. Int J Radiat Biol 80: $745-756$

Baeyens A, Thierens H, Claes K, Poppe B, Messiaen L, De Ridder L, Vral A (2002) Chromosomal radiosensitivity in breast cancer patients with a know or putative genetic predisposition. $\mathrm{Br} J$ Cancer 87: $1379-1385$

Baeyens A, Van Den Broecke R, Makar A, Thierens H, De Ridder L, Vral A (2005b) Chromosomal radiosensitivity in breast cancer patients: influence of age of onset of the disease. Oncol Rep 13: 347-353

Ban S, Konomi C, Iwakawa M, Yamada S, Ohno T, Tsuji H, Noda S, Matui Y, Harada Y, Cologne JB, Imai T (2004) Radiosensitivity of peripheral blood lymphocytes obtained from patients with cancers of the breast, head and neck or cervix as determined with a micronucleus assay. J Radiat Res (Tokyo) 45: 535-541

Battershill JM, Burnett K, Bull S (2008) Factors affecting the incidence of genotoxicity biomarkers in peripheral blood lymphocytes: impact on design of biomonitoring studies. Mutagenesis 23: $423-437$

Bolognesi C, Balia C, Roggieri P, Cardinale F, Bruzzi P, Sorcinelli F, Lista F, D’Amelio R, Righi E (2011) Micronucleus test for radiation biodosimetry in mass casualty events: evaluation of visual and automated scoring. $\mathrm{Rad}$ Measurements 46: $169-175$

Bonassi S, El-Zein R, Bolognesi C, Fenech M (2011) Micronuclei frequency in peripheral blood lymphocytes and cancer risk: evidence from human studies. Mutagenesis 26: $93-100$

Bonassi S, Znaor A, Ceppi M, Lando C, Chang WP, Holland N, Kirsch-Volders M, Zeiger E, Ban S, Barale R, Bigatti MP, Bolognesi C, Cebulska-Wasilewska A, Fabianova E, Fucic A, Hagmar L, Joksic G, Martelli A, Migliore L, Mirkova E, Scarfi MR, Zijno A, Norppa H, Fenech $M$ (2007) An increased micronucleus frequency in peripheral blood lymphocytes predicts the risk of cancer in humans. Carcinogenesis 28: $625-631$

Burrill W, Barber JB, Roberts SA, Bulman B, Scott D (2000) Heritability of chromosomal radiosensitivity in breast cancer patients: a pilot study with the lymphocyte micronucleus assay. Int J Radiat Biol 76: $1617-1619$

Couch FJ, Wang X (2009) Genome-wide association studies identify new breast cancer susceptibility genes. Curr Breast Cancer Rep 1: 131-138

Decodier I, Papine A, Plas G, Roesems S, Vande Loock K, Moreno-Palomo J, Cemeli E, Anderson D, Kirsch-Volders M (2009) Automated image analysis of cytokinesis-blocked micronuclei: an adapted protocol and a validated scoring procedure for biomonitoring. Mutagenesis 24: $85-93$

Dhillon VS, Thomas P, Iarmarcovai G, Kirsch-Volders M, Bonassi S, Fenech M (2011) Genetic polymorphisms of genes involved in DNA repair and metabolism influence micronucleus frequencies in human peripheral blood lymphocytes. Mutagenesis 26: 33-42

Djuzenova CS, Muhl B, Fehn M, Oppitz U, Muller B, Flentje M (2006) Radiosensitivity in breast cancer assessed by the Comet and micronucleus assays. Br J Cancer 94: 1194-1203

El-Zein R, Vral A, Etzel CJ (2011) Cytokinesis-blocked micronucleus assay and cancer risk assessment. Mutagenesis 26: 101-106

Fenech M (2007) Cytokinesis-block micronucleus cytome assay. Nat Protoc 2: $1084-1104$

Hsu HM, Wang HC, Chen ST, Hsu GC, Shen CY, Yu JC (2007) Breast cancer risk is associated with the genes encoding the DNA double-strand break repair Mre11/Rad50/Nbs1 complex. Cancer Epidemiol Biomarkers Prev 16: $2024-2032$
Iarmarcovai G, Ceppi M, Botta A, Orsiere T, Bonassi S (2008) Micronuclei frequency in peripheral blood lymphocytes of cancer patients: a metaanalysis. Mutat Res 659: 274-283

Kotsopoulos J, Chen Z, Vallis KA, Poll A, Ainsworth P, Narod SA (2007) DNA repair capacity as a possible biomarker of breast cancer risk in female BRCA1 mutation carriers. Br J Cancer 96: 118-125

Kwei KA, Kung Y, Salari K, Holcomb IN, Pollack JR (2010) Genomic instability in breast cancer: pathogenesis and clinical implications. Mol Oncol 4: $255-266$

Latimer JJ, Johnson JM, Kelly CM, Miles TD, Beaudry-Rodgersd KA, Lalanne NA, Vogel VG, Kanbour-Shakir A, Kelley JL, Johnson RR, Grant SG (2010) Nucleotide excision repair deficiency is intrinsic in sporadic stage I breast cancer. PNAS 107: 21725-21730

Maluf SW, Erdtmann B (2001) Genomic instability in Down syndrome and Fanconi anemia assessed by micronucleus analysis and single-cell gel electrophoresis. Cancer Genet Cytogenet 124: $71-75$

Migliore L, Coppede F, Fenech M, Thomas P (2011) Association of micronucleus frequency with neurodegenerative diseases. Mutagenesis 26: $85-92$

Moher D, Liberati A, Tetzlaff J (2009) Preferred reporting items for systematic reviews and meta-analyses: the PRISMA statement. $\mathrm{Br} \mathrm{Med} J$ 339: $332-338$

Mozdarani H, Mansouri Z, Haeri SA (2005) Cytogenetic radiosensitivity of G0-lymphocytes of breast and esophageal cancer patients as determined by micronucleus assay. J Radiat Res (Tokyo) 46: 111-116

Murgia E, Ballardin M, Bonassi S, Rossi AM, Barale R (2008) Validation of micronuclei frequency in peripheral blood lymphocytes as early cancer risk biomarker in a nested case-control study. Mutat Res 639: $27-34$

OECD TG 474 (1997) OECD Guideline for the Testing of Chemicals, No. 474: Mammalian Erythrocyte Micronucleus Test. Organization for Economic Cooperation and Development: Paris, France

OECD TG 487 (2009) OECD Guideline for the Testing of Chemicals, No. 487: In vitro Mammalian Cell Micronucleus Test (MNvit). Organization for Economic Cooperation and Development: Paris, France

Ralhan R, Kaur J, Kreienberg R, Wiesmuller L (2007) Links between DNA double strand break repair and breast cancer: accumulating evidence from both familial and non familial cases. Cancer Lett 248: 1-17

Rothfus A, Schutz P, Bochum S, Volm T, Eberhardt E, Kreienberg R, Vogel W, Speit G (2000) Induced micronucleus frequencies in peripheral lymphocytes as a screening test for carriers of a BRCA1 mutation in breast cancer families. Cancer Res 60: 390-394

Scott D, Barber JBP, Levine EL, Burrill W, Roberts SA (1998) Radiationinduced micronucleus induction in lymphocytes identifies a high frequency of radiosensitive cases among breast cancer patients: a test for predisposition? Br J Cancer 77: 614-620

Scott D, Barber JBP, Spreadborough AR, Burrill W, Roberts SA (1999) Increased chromosomal radiosensitivity in breast cancer patients: a comparison of two assays. Int J Radiat Biol 75: 1-10

Scott D, Hu Q, Roberts SA (1996) Dose-rate sparing for micronucleus induction in lymphocytes of controls and ataxia-telangiectasia heterozygotes exposed to 60Co gamma-irradiation in vitro. Int J Radiat Biol 70: $521-527$

Smith TR, Miller MS, Lohman KK, Case LD, Hu JJ (2003) DNA damage and breast cancer risk. Carcinogenesis 24: 883-889

Surowy H, Rinckleb A, Luedeke M, Stuber M, Wecker A, Varge D, Maier C, Hoegel J, Vogel W (2011) Heritability of baseline and induced micronucleus frequency. Mutagenesis 26: 111-117

Sutton A, Abrams K, Jones D, Sheldon T, Fujian S (2004) Methods for Meta-Analysis in Medical Research (Wiley Series In Probability and Statistics-Applied Probability and Statistics Section). Wiley: West Sussex, UK, cap 2 pp 23-33; cap 3 pp 62-63

Trenz K, Lugowski S, Jahrsdörfer U, Jainta S, Vogel W, Speit G (2003) Enhanced sensitivity of peripheral blood lymphocytes from women carrying a BRCA1 mutation towards the mutagenic effects of various cytostatics. Mutat Res 544: 279-288

Trenz K, Rothfuss A, Schütz P, Speit G (2002) Mutagen sensitivity of peripheral blood from women carrying a BRCA1 or BRCA2 mutation. Mutat Res 500: $89-96$

Varga D, Hoegel J, Maier C, Jainta S, Hoehne M, Patino-Garcia B, Michel I, Schwarz-Boeger U, Kiechle M, Kreienberg R, Vogel W (2006) On the difference of micronucleus frequencies in peripheral blood lymphocytes between breast cancer patients and controls. Mutagenesis 21: $313-320$ 
Varga D, Johannes T, Jainta S, Schuster S, Schwarz-Boeger U, Kiechle M, Patino Garcia B, Vogel W (2004) An automated scoring procedure for the micronucleus test by image analysis. Mutagenesis 19: 391-397

Venkitaraman AR (2002) Cancer susceptibility and the functions of BRCA1 and BRCA2. Cell 108: 171-182
Venkitaraman AR (2009) Linking the cellular functions of BRCA genes to cancer pathogenesis and treatment. Annu Rev Pathol 4: 461-487

Willems P, August L, Slabbert J, Romm H, Oestreicher U, Thierens H, Vra A (2010) Automated micronucleus (MN) scoring for population triage in case of large scale radiation events. Int J Radiat Biol 86: 2-11

This work is published under the standard license to publish agreement. After 12 months the work will become freely available and the license terms will switch to a Creative Commons Attribution-NonCommercial-Share Alike 3.0 Unported License. 